\section{A new arms race? The political economy of maritime military modernization in the Asia- Pacific}

Richard A. Bitzinger

$\mathrm{D}$ uring the 2000s, navies in the Asia-Pacific region have experienced a significant, if not unprecedented, bout of naval expansion. This buildup has been quantitative, but more importantly, qualitative as well, and in many cases goes beyond mere modernization. From Japan to Southeast Asia to India, regional maritime forces have been adding new capabilities that they did not possess earlier, and therefore the capacity for new roles and missions, to their inventories. In particular, these navies have acquired new types of ships (both surface and undersea) and aircraft that have given them capabilities for force projection and expeditionary operations that they previously lacked. In addition, they have bought new missiles and other types of munitions that have greatly increased the lethality and accuracy of their forces. And they are gaining both the hardware and the software to improve their surveillance, reconnaissance, target acquisition, and command and control. For example, most countries in the Asia-Pacific are in the process of greatly expanding their open ocean-capable navies with modern surface warships. China's People's Liberation Army Navy (PLAN) has acquired four Russian-made Sovremennyy-class destroyers, armed with supersonic SS-N-22 antiship cruise missiles; in addition, the PLAN has constructed six destroyers of three different types, and at least six frigates since 2000. Japan will soon field six Aegis-class destroyers, as well as four 13,500-ton Hyuga-class helicopter destroyers (DDH). Australia is planning to acquire and construct three Hobart-class air warfare destroyers (AWD), which will be based on the U.S. Aegis combat system and the SM-2 Standard surface-to-air missile. These AWDs will provide protection to amphibious, sealift, and support ships from aircraft and antiship cruise missiles. South Korea is constructing a series of indigenous KDX destroyers; the current third-generation KDX-III is equipped with the U.S.-supplied Aegis air-defense radar and fire-control system, and is armed with the Standard SM-2 Block IIIB air-defense missile and the indigenous Hae Sung (Sea Star) antiship cruise missile (ASCM). Singapore acquiring six Formidable-class frigates, which are based on the French-designed Lafayette-class "stealth" frigates, armed with Harpoon ASCM and the French Aster-15 air-defense missile, which is capable of providing antiballistic missile defense.

At the same time, many of these navies are also building up their submarine fleets. China has acquired 12 Russian Kilo-class diesel-electric submarines, and since the turn of the century, it has also constructed up to 16 indigenously built diesel-electric and at least three nuclear-powered submarines (including one nuclear-powered ballistic missile submarine [SSBN]). Japan is currently building a new class of diesel-electric submarines (the Soryu), outfitted with the Swedish-developed Stirling engine for air-independent propulsion (AIP). South Korea during the 1990s constructed, under license, a fleet of nine German Type-209 submarines. It is currently replacing these with the German Type-214,

which is equipped with hydrogen fuel cells for AIP; three boats were ordered in 2000 and three more in 2009. South Korea eventually hopes to design its own (possibly nuclear-powered) submarine. India is acquiring six Franco-Spanish Scorpène-class submarines, which will be constructed under license. India also wants to build its own nuclear-powered submarines, and its navy hopes to launch its first indigenous nuclear boat by 2009 and ultimately deploy a fleet of three SSBNs by 2015, armed with the indigenously developed Sagarika submarine-launched ballistic missile.

Additionally, Southeast Asia has witness an explosion in submarine-acquisition activity over the past decade. Singapore has acquired six second-hand submarines from Sweden, and may later acquire or retrofit submarines for AIP. Malaysia is buying two Scorpène-class submarines, and Indonesia plans to acquire four Kilo-class and two Lada-class submarines from Russia.

Many Asian-Pacific navies are also increasing their capacities for expeditionary and amphibious warfare. The PLAN has recently launched the Type-071 17,000 to 20,000-ton LPD (landing platform dock) amphibious warfare ship, equipped with two helicopters and two air-cushioned landing craft (LCAC), and capable of carrying up to 800 troops; up to eight Type-071s could eventually be built, and it could be complemented by a new larger LHD-type amphibious assault ship. In addition, rumors persist that the PLAN will add at least one aircraft carrier (and perhaps as many as six) to its fleet by 2015-2020. Japan's Maritime Self Defense Force (MSDF) has acquired three 13,000-ton Osumi-class amphibious warships, while the the Hyuga DDH, with its "through-deck" design and below-deck hangars, closely resembles a small aircraft carrier. Conceivably, this ship could be retrofitted with a "ski-jump" deck for fixed-wing aircraft or outfitted with vertical-lift combat jets, such as the F-35 Joint Strike Fighter (JSF). The Royal Australian Navy (RAN) plans to acquire two new 28,000-ton Canberra-class amphibious power projection (LHD-type) ships, each capable of transporting 1,000 troops and 150 vehicles (including the Australian Army's new M1A1 Abrams tanks), and carrying both landing craft and a mix of transport and battlefield support helicopters. The ROK Navy (ROKN) is acquiring the Dokdo-class amphibious assault ship, which displaces 14,000 tons and is capable of carrying 700 troops, ten tanks, 15 helicopters, and two LCACs. At least two 
Dokdo-class vessels have been ordered, and the ROKN may eventually deploy up to four such ships. India is in the process of acquiring two large-deck aircraft carriers one a former Soviet Navy vessel, the former Admiral Gorshkov, which is being extensively refitted and upgraded, and which operate navalized MiG-29 fighters, and the other an ambitious project to design and build an indigenous carrier, outfitted with either the MiG-29 or India's Tejas Light Combat Aircraft. Finally, Thailand has acquired a small aircraft carrier from Spain, while Singapore has constructed its own fleet of four small amphibious assault ships.

In terms of airpower - which can support maritime power projection - nearly every Asia-Pacific country currently possesses or is acquiring at least some fourth-generation fighter aircraft such as the Russian Su-27/Su-30 (China, India, Malaysia, Indonesia), the Russian MiG-29 (Myanmar, Vietnam), the U.S. F-16 (Indonesia, South Korea, Singapore), the U.S. F-15 (Japan, South Korea, Singapore), the U.S. F/A-18 (Malaysia), and the Swedish Gripen (Thailand). In addition, these fighter aircraft are capable of firing stand-off active radar-guided air-to-air missiles, such as the U.S. AMRAAM or the Russian AA-12, or dropping precision-guided weapons, such as the Joint Direct Attack Munition (JDAM).

In terms of air-based power projection, China, India, Japan, South Korea, Malaysia, and Singapore have all received or else will soon acquire tanker aircraft for air-to-air refueling, while Australia, China, Japan, and Malaysia are acquiring long-range transport aircraft. Both Japan and India plan as well to expand their fleet of maritime patrol aircraft with modern state-of-the-art systems.

Some Asian-Pacific militaries are acquiring the capabilities for long-range precision-strike. India, for example, is developing the Brahmos supersonic cruise missile in cooperation with Russia; the Brahmos can attack both land and sea-based targets. China has put particular stress on building up, both quantitatively and qualitatively, its arsenal of conventional ballistic missile systems, including reportedly developing a medium-range missile with an antiship capability, most likely for use against large warships such as aircraft carriers. South Korea, meanwhile, has developed its own land-attack cruise missile, the Hyunmoo IIIC. Finally, most countries in the region by now also equip their navies with sophisticated antiship cruise missiles.

Several countries in the region, including India, Japan, Korea, and Singapore, have plans to acquire missile defenses. In particular, Japan, in cooperation with the U.S. Navy (USN), is upgrading its Aegis-class destroyers with new software and a new interceptor missile, so as to be able to search, detect, track, and engage incoming ballistic threats. The MSDF and the USN successfully tested this system off the coast of Hawaii in June 2006, and Japan performed a solo missile intercept test in late 2007. Finally, most Asia-Pacific militaries are engaged in greatly expanding and upgrading their C4ISR capabilities. China, Japan, Singapore, and Taiwan all currently possess airborne early warning and command (AEW\&C) aircraft, while Australia, India, and South Korea intend to acquire AEW\&C aircraft in the near future. Both Japan and
South Korea have or will soon have the Aegis naval sensor and combat system deployed on their largest surface combatants, while Taiwan is buying long-range early warning radar. Nearly every major military in the region is acquiring unmanned aeria vehicles (UAVs) and increasingly using outer space for military purposes, including satellites for surveillance, communications, and navigation/target acquisition. Severa countries in the region, particularly Australia, China, Japan, Singapore, South Korea, and Taiwan, have also made or are presently making considerable investments in new types of information processing and data fusion, command and control, and the digitization of their armed forces.

\section{Enabling the maritime buildup \#1: rising military expenditure}

Rising military budgets have underwritten the arms buildup in the Asia-Pacific over the past decade. The Chinese military, for example, has long been the beneficiary of a long-term expansion in military expenditure. Between 1997 and 2005, Beijing increased defense spending by double-digit doses every year: 13.7 percent per annum, in real, i.e., after inflation, terms, according to the Chinese's own statistics. ${ }^{1}$ China's official 2009 budget of US\$70.2 billion, for example, constitutes a 14.9 percent rise over the previous year. Consequently, Chinese military expenditure has more than quintupled in real terms since 1997, permitting China to put considerable additional resources into the hardware and software of military modernization. China now outspends Japan (US\$48.8 billion), France (US\$58.9 billion), and the United Kingdom (US $\$ 66.8$ billion) on national defense, and likely Russia as well (estimated 2009 defense budget, US\$37.7 billion). ${ }^{2}$

Other Asian-Pacific nations have not stood still. Indian defense spending rose 37 percent (in real terms) between 2000 and 2007, according to data provided by the Stockholm International Peace Research Institute (SIPRI); in 2008, New Delhi announced that it would raise its military budget by 10 percent over the previous year. Moreover, India plans to spend at least US\$30 billion on new arms by 2012. Australia has increased defense spending by 42 percent over the same 2000-2007 period, while South Korea's has increased by 35 percent. Of all the larger countries in the Asia-Pacific, only Japan and Taiwan have had relatively static military budgets (but in 2008, Taiwan announced a 15 percent increase in defense spending over 2007, to US\$10.3 billion). ${ }^{3}$

Military expenditure in Southeast Asia has also recovered from its depths during reached the Asian financial crisis of the late 1990s. Malaysia's military budget has more than doubled between 2000 and 2007, from US\$1.7 billion to US $\$ 3.5$ billion (as measured in constant 2005 dollars). Indonesian defense spending over the same period went from US $\$ 2.2$ billion to US\$4.2 billion, a 90 percent increase, a figure that does not include weapons purchases using export credits. And Singapore's defense budget rose 33 percent, from US\$4.6 billion in 2000 , to US\$6.1 billion in 2007; in 2008, Singapore's military budget totaled US $\$ 7.5$ billion. ${ }^{4}$ 
After the 2006 coup the Thai military junta approved a 34 percent increase in the 2007 defense budget, and a further 24 percent rise in 2008. In November 2007, the military proposed a new ten-year, 317 billion baht (US\$9.8 billion) modernization program, starting in 2009 , which would push military expenditure from 1.58 percent of GDP to 2 percent by 2014 .

Enabling the maritime buildup \#2: the global buyer's market in armaments

Along with rising regional military expenditure, the highly competitive nature of the current global arms market has meant that there are many motivated sellers on the supply side of the arms business. In the post-cold war era, almost every major arms-manufacturing country has come to depend heavily on overseas sales to bulk up their business. As domestic arms markets have shrunk, the overseas business sector has correspondingly grown in importance. For their part, European defense firms have come to be highly dependent upon foreign sales. In 2007, for example, BAE Systems did only 22 percent of its business in the United Kingdom; the rest was overseas. Thales generated roughly 75 percent of its 2008 revenues from outside France, while Dassault exported 70 percent of its output, and Saab, 68 percent. This trend corresponds with experiences of arms-producing countries elsewhere in the world. Israel's defense industry, for example, typically exports more than three-quarters of its output. The Russian defense industry also has a "substantial dependence" on arms exports; the collapse of the home market for arms sales, following the breakup of the Soviet Union, has resulted in a situation whereby Russian defense companies have come to rely on oversea business for between 80 to 90 percent of their total sales. ${ }^{5}$

The U.S defense industry, with its huge captive domestic arms market, is typically not as dependent upon overseas sales as its European, Russian, and Israeli counterparts. The major U.S. defense companies garner only a small percentage of their revenues, typically around 5 to 15 percent, from non-U.S. markets. Nevertheless, by the turn of the century, several major American weapons systems, such as the F-15 and F-16 fighters and the M1A1 main battle tank, were being produced solely for export. Additionally, one current U.S. weapons program, the F-35 Joint Strike Fighter (JSF), depends heavily upon foreign funding, foreign industrial participation, and anticipated foreign sales. ${ }^{6}$

Overall, for many defense firms, therefore, overseas sales are no longer a supplemental form of income; they are increasingly critical to the health of the affected firm and that of the defense industrial base. At the same time, the global arms market has become more complex and competitive. The large numbers of motivated sellers in the West created a buyer's market in arms in which nearly every conceivable kind of conventional weapon system was on the table. Additionally, the end of the cold war division of the world into communist and capitalist camps greatly opened up the global defense market, and arms sales were, for the most part, no longer restricted for ideological reasons. Consequently, arms exporters had to be ready to deal, and offering potential buyers incentives such as industrial participation (offsets), technology transfers, and foreign direct investments, increasingly became part of the cost of doing business.

At the same time, the Asia-Pacific region has become a major importer of advanced conventional weaponry. It is second only to the Middle East when it comes to global arms purchases, importing nearly US\$67 billion worth of arms between 2000 and 2007, according to data compiled by the U.S. Congressional Research Service (CRS). In terms of arms transfer agreements, it was the largest market during the 2000-2003 time frame. Some of world's biggest arms buyers are found in the region. China, for example, received US\$17 billion worth of weapons systems between 2000 and 2007 - only Saudi Arabia imported more armaments. During this same period, India imported US\$11.5 billion worth of arms, Taiwan US\$8.4 billion, and South Korea US\$6.6 billion.?

Accordingly, the Asia-Pacific is a critical market for the world's leading arms suppliers. During the period 2000-2007, for example, 75 percent of all Russian arms deliveries, US\$26 billion worth, went to this region, mainly to China and India but also increasingly to Indonesia, Malaysia, and Vietnam, according to CRS data. Russia is also consistently the largest exporter of arms to the region. During the same period, the leading European arms producers, the United Kingdom, France, Germany, and Italy, signed arms sales agreements with the region totaling US\$14.4 billion. In all, 54 percent of France's arms sales agreements were with Asia-Pacific countries, as were 53 percent of Germany's and 44 percent of Italy's (only for the United Kingdom was the region a relatively small percentage of overall arms agreements, 13 percent during 2000-2007, and mostly due to an extraordinary large sale of Typhoon fighter jets and other equipment to Saudi Arabia). ${ }^{8}$

The U.S. defense industry also relies heavily on sales to the Asia-Pacific. During the period 2000-2007, it delivered over US\$19 billion worth of armaments to the region, or approximately one-third of all its overseas deliveries. Only the Middle East, at US\$36 billion worth, was a larger arms market for the United States. ${ }^{9}$

The Southeast Asian arms market is particularly noteworthy, because, while it is relatively small, collectively worth around US\$2 billion to US\$3 billion annually, it is also one of the more truly open and competitive markets when it comes to arms sales (compared to China or India, which mostly buy from Russia, or Japan or Taiwan, which are more or less captive markets of the U.S. defense industry). While the United States, for example, dominates Southeast Asia in the sale of fighter aircraft (e.g., F-15s to Singapore; F-16s to Indonesia, Singapore, and Thailand; F/A-18s to Malaysia), the United Kingdom has scored particular success in exporting its Hawk trainer jet to Malaysia and Indonesia. Germany, meanwhile, has sold submarines to Indonesia and corvettes to Malaysia and Singapore; France, frigates to Singapore and antiship cruise missiles to Indonesia, Malaysia, Singapore, and Thailand; Russia, Su-30 fighters to Malaysia, Indonesia, and Vietnam; and Sweden, submarines to Singapore. Malaysia and Singapore constitute the largest arms buyers in Southeast 
Asia; during 2002-2005, for example, Kuala Lumpur placed orders for US\$2.8 billion worth of arms.

Given the size and strength of the regional arms market, it is not surprising that this area has become a critical market, and therefore the object of particularly fierce competition, for the world's leading arms suppliers, particularly the United States, Western Europe, Russia, and Israel. Consequently, supplier restraint has been replaced by a readiness to sell just about every type of conventional weapon system available to the region, and, in addition, to use technology transfers and offsets as inducements to make an arms sale. Such sweetheart deals, therefore, can have as much impact on what kind of arms that Asian-Pacific militaries buy as can actual threats or military requirements.

\section{Repercussions of the Asian-Pacific arms buildup}

It is apparent that it is the economics of armaments production, particularly the drive for market share among the leading, competing arms-producing nations, that are increasingly propelling military modernization in the Asia-Pacific region. As domestic arms markets stagnate, U.S., European, Russian, and Israeli defense firms have been forced to go abroad in search of new customers for their products, usually with the consent or even the urging of their governments. As the competition within the ever-tighter global arms market has grown, so too have suppliers been increasingly willing to offer almost every conceivable type of conventional weapon in their catalog.

Under such circumstances, it is appropriate to consider the impact of such a policy and in particular to question the wisdom of such a course when it comes to the long-term security of the Asia-Pacific region. Countries, of course, have the right to legitimate self-defense, and therefore the right to maintain an armed force with sufficient capabilities to meet its perceived requirements. But it is also apparent that the regional process of military modernization can have unintended consequences. The easier availability of the most advanced conventional weapons is going to have an obvious impact on conventional arms proliferation in the region, thus ratcheting up regional military balances and at least indirectly compounding regional military tensions, i.e., the so-called security dilemma. Nowhere is this more evident than in the Taiwan strait situation. China's growing arsenal of more modern warships, submarines, fighter aircraft, and precision-guided munitions has certainly increased Taiwan's threat perceptions of China, and it has fueled Taiwan's counter-acquisition of new air and missile defenses, anti-submarine and anti-surface warfare systems, and counter-landing weapons. Yet, as these militaries become more capable, the situation across the Taiwan strait has not necessarily become less tense - just the opposite, in fact, as armed forces on both sides increasingly test each other's strengths and weaknesses in the strait. Such concerns are only multiplied when one considers the types of military systems being acquired, transformational weapons that promise to fundamentally change the conduct of warfare and which could greatly increase its destructiveness.

Moreover, without necessarily leading to arms races, these new arms acquisitions can lead to very expensive, and ultimately imprudent, arms competitions, or what Barry Buzan and Eric Herring have called the arms dynamic. ${ }^{10}$ Such arms competitions are usually defined as non-cataclysmic, status quo-oriented rivalries, dedicated mainly to the maintenance of military balances; however, they can still be disruptive to regional security and can perhaps even evolve into arms races. Just as important, they can act to redirect monies from arguably more critical defense needs For example, South Korea's efforts to acquire a blue-water navy (complete with a large fleet of ocean-going submarines), intended to rival Japan's and China's maritime forces, could have the effect of drawing resources away from defending against an attack from North Korea.

Additionally, when it comes to the poorer countries in the Asia-Pacific, one might question the wisdom of such arms purchases from an economic aspect, particularly if these acquisitions divert considerable funds away from more pressing social needs. This is particularly apropos when it comes to Southeast Asia: does Thailand, for example, actually need an aircraft carrier, especially one that was so expensive to acquire and to operate and is of such little strategic value? Should Western countries sell certain types of armaments, such as modern submarines or AMRAAM-type air-to-air missiles, to countries in Southeast Asia when the release of such weapons systems could have far-reaching implications for regional security dynamics? (A moot point, unfortunately.) In the end, the only actors who may actually benefit from increased arms sales to the region may be the sellers.

In conjunction, are local efforts at defense industrialization, often via licensing or offset coproduction, an efficient use of scarce economic development resources, or are these undertakings simply creating industrial white elephants? Witness, for example, Indonesia's decades-long effort to establish an indigenous aircraft industry, at the cost of billions of dollars, but with very little to show for it: by the late 1990s, the state-owned Industri Pewsawat Terban Nusantara (IPTN) had grown to a workforce of almost 16,000, and the company was intending to become "the Toyota of aerospace,' with an aircraft to meet every niche in the 20 to 130 -seat range." In fact, Indonesia appeared to be making considerable strides toward meeting its goals of self-sufficiency and toward creating a world-class defense and commercial aerospace sector. In particular, it had one major indigenous program, the N-250 commuter plane, already flying and another, the N-2130 regional jet, on the drawing board. Much of this apparent success was illusory, however, and Indonesia was by the late 1990s already finding it increasingly difficult to maintain its domestic aircraft industry. The Indonesian government poured nearly US\$1 billion into the N-250 program, for example, but despite this huge investment, the aircraft continued to experience considerable teething problems. Eventually, the 1997-98 Asian financial crisis forced Jakarta to dramatically scale back its aerospace industry. The company 
has since shrunk its workforce to around 3,500 employees and most of its several key manufacturing projects are on permanent hold. ${ }^{11}$

Overall, it is unlikely that the region will rein in its multifaceted military modernization programs anytime soon. So long as military expenditure across the region continues to rise, and so long as leading arms suppliers outside the region continue to sell practically every kind of weapon to local militaries, the Asian-Pacific strategic calculus is unlike to change much. One obvious solution, of course, is to call for more self-restraint on the part of the outside arms suppliers; at the same time, this is almost impossible to do, especially so when it comes to conventional armaments. As opposed to weapons of mass destruction, the threshold of perceived illegitimacy of such arms sales is extremely high and perhaps even nonexistent. Consequently, conventional arms transfers constitute a classic prisoner's dilemma: if one producer decides to demonstrate self-restraint in exporting a particular type of weapon system, its competitors will usually not hesitate to fill the void.

The challenge, obviously, is securing a multilateral agreement among the leading arms producers, particularly the United States and Western Europe, to limit sales to areas where they could have the most negative economic as well as security impacts. Restricting the number and types of armaments exported to the Asia-Pacific may be one region where Western supplier-states could begin to implement such a policy. All this, of course, requires a greater readiness on the part of the leading arms producers to accept some short-term economic losses in exchange for longer-term regional security benefits. That, in turn, requires that the United States and Western Europe find common ground on the wider strategic, military, and political benefits of exercising multilateral self-restraint in the region, not a very encouraging prospect.

At the same time, supplier restraint does not resolve the issue of growing local appetites for more and more sophisticated types, coupled with the fact that many Asian-Pacific states are increasingly capable of producing many such arms themselves. Overall, it is probably unrealistic to assume that the accelerating modernization of local militaries (and not just navies, but air and ground forces as well) will abate on its own. The economic realities of military modernization in the Asia-Pacific are such that the current state of affairs is not likely to change anytime soon.

\section{Notes}

Richard A. Bitzinger is a Senior Fellow at the S. Rajaratnam School of International Studies, Nanyang Technological University, Singapore. He can be reached at isrbitzinger@ntu.edu.sg.

\section{China (2006).}

2. SIPRI (2009)
3. New Delhi 10\%: see India-Defense (2008). 2012: see Raghuvanshi (2008). South Korea 35\%: see SIPRI (2009). Taiwan 15\%: see Reuters (2007).

\section{SIPRI (2009)}

5. Vatanka and Weitz (2006).

6. The JSF program office expects to sell at least 25 percent, or 730 aircraft, of the first batch of F-35s to the nine nations currently participating in the aircraft's development phase; this figure does not include export sales to other countries, particularly Israel, which has already announced its intention of buying around 100 F-35's (see http://www.jsf.mil/downloads/documents/ANNEX\%20A\%20Revision_ April\%202007.pdf).

\section{See Grimmett (2008, Tables 2C, 1C, and 2I).}

8. Grimmett (2008). Importer data derived from Tables 2 and 2C. Exporter data derived from Tables 1 and $1 \mathrm{C}$.

9. Grimmett (2008, Tables 2 and 2C).

10. Busan and Herring (1998).

11. Quote: Bailey (1992). Teething problems: Cohen (2000). 3,500 employees: Karnoil (2004).

\section{References}

Bailey J. 1992. “Habibie’s Grand Design.” Flight International. 19 February 1992, pp. 51-52.

Busan, B. and E. Herring. 1998. The Arms Dynamic in World Politics. Boulder, CO: Lynne Rienner.

[China] Information Office of the State Council of the People's Republic of China. 2006. "China's National Defense in 2006. Chapter IX: Defense Expenditure.'

Cohen M. 2000. "New Flight Plan.” Far Eastern Economic Review. 2 March 2000, p. 45.

Grimmett, R. 2008. "Conventional Arms Transfers to Developing Nations, 2000-2007.” Washington, D.C.: Congressional Research Service.

[India-Defense]. 2008. "10 Per cent Hike in Indian Defense Budget for 2008-09." India-Defence. 2 March 2008. http://www.india-defence.com/reports-3759 [accessed 4 April 2008].

International Institute for Strategic Studies. 2009. The Military Balance 2009. 
London: Routledge.

Karnoil R. 2004. "Country Briefing: Indonesia - Interior Designs.” Jane's Defence Weekly. 21 March 2004.

Raghuvanshi, V. 2008. "India Launches First Defense Investment Fund." Defense News. 7 July 2008.

[Reuters]. 2007. "Taiwan Plans Big Increase in Defense Spending." International Herald Tribune. 23 August 2007.

Stockholm International Peace Research Institute (SIPRI). 2009. “The SIPRI Military Expenditure Database.” http://milexdata.sipri.org [accessed 10 February 2009].

Vatanka A. and R. Weitz. 2006. "Russian Roulette — Moscow Seeks Influence Through Arms Exports." Jane's Intelligence Review. 6 December 2006. 